University of Chicago Law School

Chicago Unbound

Journal Articles

Faculty Scholarship

1971

\title{
Labor Arbitration and Overlapping and Conflicting Remedies for Employment Discrimination
}

Bernard D. Meltzer

Follow this and additional works at: https://chicagounbound.uchicago.edu/journal_articles

Part of the Law Commons

\section{Recommended Citation}

Bernard D. Meltzer, "Labor Arbitration and Overlapping and Conflicting Remedies for Employment Discrimination," 39 University of Chicago Law Review 30 (1971).

This Article is brought to you for free and open access by the Faculty Scholarship at Chicago Unbound. It has been accepted for inclusion in Journal Articles by an authorized administrator of Chicago Unbound. For more information, please contact unbound@law.uchicago.edu. 


\title{
Labor Arbitration and Overlapping and Conflicting Remedies for Employment Discrimination*
}

\author{
Bernard D. Meltzerf
}

Labor arbitrators and other tribunals face serious problems of coordination as the result of overlap, as well as conflict, between arbitration systems and a broad array of public regulation. Overlap and conflict have increased as both collective agreements and the regulation that governs them have become more complex and detailed.

Remedies in some areas, such as employment discrimination on account of race or sex, run like water. ${ }^{1}$ If employment discrimination occurred in an enterprise under contract with the federal government, a remedy might be provided by the National Labor Relations Board, state courts, federal courts, state and municipal fair employment agencies, or the Department of Labor. Remedies might be based not only on the statutes and executive orders that these forums call to mind but also on the Civil Rights Act of 1866, ${ }^{2}$ the Fair Labor Standards Act as amended in 1963,3 the Age Discrimination in Employment Act of 1967,4 the Constitution, and ancient equitable doctrines making representative powers powers in trust. ${ }^{5}$ Furthermore, standards embodied in

- This paper was the basis for a talk delivered on October 15, 1971 at the Conference on Arbitration, held in Buffalo, New York under the auspices of the Federal Mediation and Conciliation Service, the American Arbitration Association, and the Industrial Relations Research Association for Western New York. The author expresses indebtedness to his colleague, Prof. Owen M. Fiss, for helpful suggestions.

† James Parker Hall Professor of Law, The University of Chicago.

1 See generally Peck, Remedies for Racial Discrimination in Employment: A Compara. tive Evaluation of Forums, 46 WASH. L. REv. 455 (1971).

214 Stat. 27 (1866).

329 U.S.C. $\$ 206$ (d) (1964).

429 U.S.C. $\$ \$ 621-34(1970)$.

5 Although the duty of fair representation is typically derived solely from statutory provisions for majority rule and exclusive representation, general equitable or tort principles would appear to warrant the imposition of such a duty on any union that purports to represent employees regardless of whether the union enjoys statutory protection. $C f$. A. Berle, Studies in the Law of Corporate Finange 46, 63 (1928).

Another possible, if specialized, remedy is suggested by the Equal Employment Opportunity Commission's petition to the Federal Communications Commission to consider the allegedly discriminatory employment practices of American Telegraph and Telephone 
or read into collective agreements and enforced through the grievancearbitration process might provide an additional remedy.

Initially, Congress and other organs of government were preoccupied with creating remedies for a deep-seated affliction of our society and largely ignored the coordination of remedies. The problem of coordination could not, however, be avoided for long. As the remedial machinery was invoked, inescapable friction among its overlapping parts heightened concern with the question of how public remedies were to be coordinated with each other and how each of those remedies was to be integrated with the arbitration system. I propose to concentrate on one aspect of the latter question-that is, the interaction of arbitration and the remedies provided by Title VII of the Civil Rights Acts of $1964^{6}$-and to deal with four interdependent questions raised by such interaction:

First, how should arbitrators handle Title VII issues that overlap with issues concerning the interpretation or application of a collective bargaining agreement?

Second, when such overlap exists, under what circumstances, if any, should an arbitral determination-or a settlement in the grievance process without arbitration-bar an employee from invoking his or her Title VII remedy?

Third, when a Title VII remedy overlaps a remedy under a collective agreement, under what circumstances, if any, should an individual claimant be required to exhaust the grievance-arbitration procedure?

Fourth, what effect should initial recourse either to arbitration or to contractual remedies have on pertinent limitation periods?

I

In dealing with grievances that implicate statutory as well as contractual provisions, ${ }^{7}$ we should distinguish between two situations. In

Corporation in connection with the latter's request for a rate increase. See Developments in the Law-Employment Discrimination and Title VII of the Civil Rights Act of 1964, 84 HARv. L. REv. 1109, 1241 (1971) [hereinafter cited as Developments]. Some of the grounds on which that petition rests would be equally applicable to a broad range of federal and state rate-making proceedings.

642 U.S.C. $\$ \S 2000 \mathrm{e}$ to $2000 \mathrm{e}-15$.

7 My discussion of such grievances will summarize my more generalized presentation at the 1967 meeting of the National Academy of Arbitrators. See Meltzer, Rtminations About Ideology, Law, and Arbitration, 34 U. CHI. L. Rev. 545 (1967), in The Arbitrator, ThE NLRB, and the Courts: Proceedings of the Twentieth Annual Meeting, National ACADEMY OF ARBITRtors 1, 14-19 (D. Jones ed. 1967). For a response and a rejoinder, compare Mittenthal, The Role of Law in Arbitration, in DEvelopments IN AMERICAN AND Foreign Arbitration: Proceedings of the Twenty-First annual Meeting; National 
the first situation, the contractual and statutory standards are not in conflict but overlap, so that a question of fact or interpretation is common to both the statutory and contractual claims. In the second, there is an unavoidable conflict between the contract and the statute, so that the arbitrator must, in effect, repudiate the contract in order to enforce the statute.

The first situation would arise if, for example, an agreement barred discrimination in employment on grounds of race and a grievance protested that failure to promote a Negro violated the contractual provision. Everyone seems to agree that an arbitrator in resolving that question should, or at least could, properly take account of the policy of and decisions under Title VII. ${ }^{8}$ In such a situation, there is no necessary incompatibility between the contractual and statutory standards. Furthermore, the parties formulated the contractual standard loosely, presumably for the purpose of permitting consideration of all relevant factors, including relevant public regulation. In considering such regulation, an arbitrator is not adding to or derogating from the agreement but is carrying out his classic role as interpreter and monitor of the bargain. ${ }^{\circ}$ Similarly, where a contractual standard is susceptible to two interpretations, one compatible with, and the other repugnant to, an applicable statute, the statute is a relevant factor for interpretation. Arbitral interpretation of agreements, like judicial or administrative interpretation of statutes, should seek to avoid a construction that would be invalid under a higher law.

Let us turn now to the second situation, involving a conflict between the agreement and the statute, and assume the following case: The parties by their agreement have provided that certain aptitude tests may be used in determining who shall be promoted. The designated tests are, however, contrary to guidelines adopted by the Equal Employment Opportunity Commission or to court decisions. A Negro

ACADEMY OF ARBITRATORs 42 (C. Rehmus ed. 1968), with Meltzer, The Role of Law in Arbitration: A Rejoinder, in id. at 58. See also Sovern, When Should Arbitrators Follow Fedetal Law?, in Arbitration and the Expanding Role of Neutrals: Procepdings of the Twenty-Third annual Meeting, National Academy of Arbitrators 29 (G. Somers \& B. Dennis eds. 1970). This question has also been discussed in Platt, The Relation Between Arbitration and the Civil Rights Act of 1964, 3 GA. L. REv. 398 (1968).

8 See, e.g., Mittenthal, supra note 7, at $42-43$.

- See Shulman, Reason, Contract and Law in Labor Relations, 68 HARv. L. Rev. 999, 1016 (1955): "A proper conception of the arbitrator's function is basic. He is not a public tribunal imposed upon the parties by superior authority which the parties are obliged to accept. He has no general charter to administer justice for a community which transcends the parties. He is rather part of a system of self-government created by and confined to the parties. He serves their pleasure only, to administer the rule of law established by their collective agreement." 
employee denied a promotion because of low test scores files a grievance under the agreement, which restricts the arbitrator's authority to the interpretation or administration of the agreement and directs him not to add or detract from it. I have suggested, and most arbitrators appear to agree, ${ }^{10}$ that in such a situation the arbitrator should respect the agreement and ignore the law. There is no reason to credit arbitrators as a class with any special competence with respect to the law.11 Furthermore, if the arbitrator selected by the parties invoked the law to defeat their agreement, he would be going beyond the authority conferred by the submission agreement. He would also be moving into areas in which courts or other official tribunals, and not arbitrators, have been granted plenary authority. The extremely limited judicial review and the substantial finality applicable to awards enforcing the contract are based on assumptions concerning the special institutional competence of arbitrators to treat contractual issues and the parties' consent to such treatment. ${ }^{12}$ Such competence or consent cannot, however, be properly assumed with respect to awards enforcing the law and abrogating the contract. Indeed, such awards would be vulnerable to

10 See Edwards \& Kaplan, Religious Discrimination and the Role of Arbitration Under Title VII, 69 Mrch. L. REv. 599, 645 n.25 (1971).

11 Dean Sovern has suggested that there is an inconsistency in my saying that arbitrators are competent to take account of statutory provisions in resolving contractual ambiguities and in my also saying that arbitrators, absent special authorization from the parties, are not competent to declare contractual provisions invalid as repugnant to statutory provisions. Sovern, supra note 6 , at 34 . Although his suggestion is plausible, it ignores, I believe, several important considerations. When parties adopt elastic contractual standards, the conclusion that the parties "intended" an arbitrator, in interpreting or applying such standards, to consider relevant statutory or social considerations seems justified. This consideration may, of course, impose substantial burdens on a particular arbitrator, but such burdens are an inescapable incident of the arbitrator's obligation to enforce the contract. Accordingly, such burdens are within an arbitrator's institutional competence even though they may strain his personal competence. It is true that "institutional competence" may be challenged as a question-begging phrase. But classic statements of the arbitrator's role, such as Shulman's (note 9 supra), affect the parties' expectations and would warrant a distinction between the use of law as an element of interpretation and its use as a basis for invalidating unambiguous contractual standards. Such a distinction would, moreover, reduce the number of situations in which the personal competence of an arbitrator would be strained.

12 See United Steelworkers v. Warrior \& Gulf Navigation Co., 363 U.S. 574, 582 (1960), in which Justice Douglas stated: "The labor arbitrator is usually chosen because of the parties' confidence in his knowledge of the common law of the shop and their trust in his personal judgment to bring to bear considerations which are not expressed in the contract as criteria for judgment. The parties expect that his judgment of a particular grievance will reflect not only what the contract says but, insofar as the collective bargaining agreement permits, such factors as the effect upon productivity of a particular result, its consequence to the morale of the shop, his judgment whether tensions will be heightened or diminished." 
attack on the basis of the celebrated dictum in United Steelworkers $v$. Enterprise Wheel \& Car Corp.:.13 "[The award] may be read as based solely upon the arbitrator's view of the requirements of enacted legislation, which would mean that he exceeded the scope of the submission."

Some discussions regarding the role of law in arbitration invite a word of clarification with respect to the sense in which I have just referred to the "competence of arbitrators."14 What I have in mind is "institutional" rather than "personal" competence, and I base my conclusion about institutional competence on the underlying purpose of arbitration as a vehicle of protest against departures from the bargain, on the predominantly consensual nature of arbitration, ${ }^{15}$ on the fact that many arbitrators lack legal training, and on the presuppositions underlying the generally limited judicial review of arbitral awardsnamely, that the arbitrator's expertise and the parties' consent extend only to arbitral treatment of contractual issues. These institutional considerations should, I believe, be respected even though a particular arbitrator happens to be, or happens to think that he is, qualified to deal with the law that appears to invalidate a contractual provision. Even though John Kenneth Galbraith has just reminded us again that modesty is an overrated virtue; vanity, or self-evaluation, even when or especially when coupled with the itch to do good, is a doubtful basis for jurisdiction. ${ }^{16}$ Furthermore, the fact that what are often the acci-

13363 U.S. 593, 597 (1960).

14 See Mittenthal, supra note 7, at 48; Sovern, supra note 7, at 34-35, 38.

15 It is true that in John Wiley \& Sons v. Livington, 376 U.S. 543, 549-50 (1960), labor policy as well as consensus was held to affect issues cognizable in arbitration. See Sovern, supra note 7, at 36-37. Nevertheless, quite apart from the difficulties associated with Wiley and its progeny, voluntarism persists as a fundamental ingredient of our labor relations system. When the law provides an independent remedy for a particular evil, there is, I believe, no adequate justification for an arbitrator's dilution of voluntarism on the basis of his determination that he is qualified to apply the law. But see Sovern, supra note 7, at 38, 40; cf. H.K. Porter Co. v. NLRB, 397 U.S. 99, 103-04, 108 (1970); Burns Int'l Detective Agency v. NLRB, 77 L.R.R.M. 2081 (2d Cir. 1971). Since, as is suggested in note 17 infra, judicial deference to arbitral determination of legal issues would be inappropriate, the benefits from such arbitral determination do not seem to warrant the costs involved. Cf. Aksen, Arbitration and Antitrust-Are They Compatible?, 44 N.Y.U.L. REv. 1097; Lovinger, Antitrust Issues as Subjects of Arbitration, 44 N.Y.U.L. REv. 1085, 1094; Pitosky, Arbitration and Antitrust Enforcement, 44 N.Y.U.L. REv. 1073, 1076 (1969).

16 But see Note, 32 OHro ST, L.J. 395, 405-06 (1971), which reports that a large percentage of the members of the National Academy of Arbitrators, responding to a questionnaire, affirmed their own competence to deal with legal questions. The note concludes that arbitrators should deal with such questions. Regrettably, the student editors did not deal with the possibility that failure to reply was correlated with lack of knowledge; nor did they show any skepticism with respect to self-serving. responses. 
dents of the selection process turn up an arbitrator qualified to apply the pertinent law does not mean that the parties have authorized him to nullify their agreement by recourse to statutory standards. Surely, if the parties wish to confer such authority, unambiguous language for doing so is readily at hand before the arbitration hearing or after it has begun.

When an arbitrator, despite the lack of such authorization, relies on the law to defeat the collective agreement, he may create other difficulties, which have generally been overlooked. Under such circumstances, it is likely that the legal issues were not considered in the grievance process and that one or both of the parties' representatives would not be qualified to deal with them during the arbitration hearing. ${ }^{17}$ In the latter event, the arbitrator might be confronted with uncomfortable alternatives. He could rely on an inadequate presentation of the legal issues during the hearing, or he could go beyond such a presentation and thereby defeat the normal expectation that his award is to be based on the evidence and considerations developed during the arbitration hearing. Although this dilemma might be resolved, wholly or partially, by procedural expedients, such as continuances and posthearing statements, resort to such devices would both reshape the parties' submission and increase the already considerable delays of arbitration.

\section{II}

Even if arbitrators give the law the limited role I have suggested above, they will sometimes resolve issues that would be plainly cognizable under Title VII, arbitration aside. Such resolutions give rise to our second question: Under what circumstances, if any, should an arbitral award foreclose an employee from invoking his or her Title VII remedy? Although various circuits have made pronouncements that may be read as negating such foreclosure, ${ }^{18}$ it appears that the

17 Dewey v. Reynolds Metals Co., 429 F.2d 324 (6th Cir. 1970), affd, 402 U.S. 689 (1971), discussed in text at notes 25-29 infra, seems to illustrate this situation. The union was not represented by an attorney in the arbitration.

18 See, e.g., Bowe v. Colgate-Palmolive Co., 416 F.2d 711, 715 (1969); Hutchings v. United States Indus., Inc., 428 F.2d 303, 311-14 (5th Cir. 1970). It should be noted that the court in Hutchings left for the future the question whether courts dealing with Title VII might follow the NLRB practice of deferring to arbitration when certain standards are met. Id. at $314 \&$ n.10. Furthermore, in Bowe, the Seventh Circuit declared generally that the analogy to concurrent NLRB and arbitral jurisdiction was "controlling" in holding that a grievant was not required to elect between statutory and contractual remedies prior to a decision on the merits in any forum. 416 F.2d at 714. If after an arbitration award had been rendered the NLRB practice were "conclusive" for Title VII, courts under some circumstances would defer to such awards. See text and note at note $\mathbf{5 2 .}$ 
Sixth Circuit is the only federal court of appeals that has ruled squarely on that matter. Its position, first announced in Dewey $v$. Reynolds Metals Co., ${ }^{19}$ was that an arbitral denial of a claim of employment discrimination barred the claimant from pursuing his Title VII remedies. The decision in Dewey was affirmed last term by an equally divided Supreme Court. ${ }^{20}$ It should be noted that the Sixth Circuit, although holding that the arbitral determination barred judicial consideration of the merits of the alleged statutory violation, also concluded that no violation of Title VII had occurred. Consequently, there is doubt whether any or all of the four Justices of the Supreme Court who voted for affirmance accepted the Sixth Circuit's views with respect to arbitral foreclosure of statutory remedies. The fact that no other circuit has expressly adopted foreclosure, coupled with the ambiguity of the Supreme Court's decision, invites a closer look at the Sixth Circuit's disposition of the Dewey case.

Dewey had worked in a Reynolds Metals plant in Michigan for fifteen years before his discharge in 1966 for violating the company's policy with respect to compulsory overtime. Beginning in 1960, collective agreements with the United Auto Workers, to which Dewey belonged, provided that all employees were obligated to perform all straight time and overtime work required of them by the company in the absence of "a substantial and justifiable reason for not working." In September, 1965, apparently after the union had expressed some concern about compulsory overtime, the company issued an interpretation of the agreement allowing an employee to be relieved of an overtime assignment by arranging for a qualified employee to replace him. Dewey, a member of the Faith Reformed Church since 1961, first refused to carry out a Sunday overtime assignment on November 21, 1965, basing his refusal on his religious beliefs. He received a warning. During the next nine months, another qualified employee replaced Dewey whenever the latter was scheduled for Sunday overtime. But subsequently Dewey called off his replacement and stated that securing a replacement contravened his religious convictions, which were conceded to be sincere. Subsequent refusals by Dewey to work on Sundays or to secure a qualified replacement led to his discharge.

Dewey thereupon took ample advantage of the remedial arsenal. $\mathrm{He}$ filed a grievance under the collective agreement and simultaneously filed a charge with the Michigan Civil Rights Commission. The Commission ruled against him, and he turned to the United States Office of Federal Contract Compliance, which also rebuffed him. But in January,

19429 F.2d 324 (6th Cir. 1970), affd, 402 U.S. 689 (1971)..

20402 U.S. 689 (1971). 
1967, the EEOC rewarded his persistence, overruling its regional director, finding probable cause, and authorizing Dewey to sue in a federal district court.

Before Dewey filed suit, Mark Kahn, a respected economist-arbitrator, denied his grievance in an award dated June 29, 1967. At the arbitration proceeding, Dewey had been represented by a union official, but not by an attorney, although the company had been so represented; and the company, but not the union, had filed a posthearing brief.21 The collective agreement did not contain a provision barring religious discrimination, but it did contain a provision denying the arbitrator authority to add to, detract from, or modify the agreement.

Mr. Kahn's denial of the grievance rested on two basic findings. First, the "substantial and justifiable reason" for not performing overtime assignments, although it justified an occasional refusal to work overtime, did not warrant a refusal to do all Sunday work. ${ }^{22}$ Second, the contract required Dewey to "utilize the established replacement procedure in order to minimize or perhaps avoid entirely the need to confront the company with a refusal of Sunday work." ${ }^{23}$ The arbitrator's opinion said nothing about the statute-either as a source of extra contractual rights or as a guide to interpreting the plastic contractual phrase "substantial and justifiable reason."24 The company's brief had also been silent about those matters.

The district court first held that the adverse arbitral determination did not foreclose Dewey from pursuing his remedy under Title VII ${ }^{25}$ and subsequently sustained Dewey's claim on the merits, ${ }^{26}$ relying on Sherbert $v$. Verner, ${ }^{27}$ on the absence of proof that Dewey's refusal to work on Sundays would impose hardship on the company, and on the EEOC guidelines, ${ }^{28}$ notwithstanding their issuance after the fact of the discharge. ${ }^{20}$

21291 F. Supp. 786, 789 (W.D. Mich. 1968).

22 Reynolds Metals Co. v. Local 227, UAW (unpublished award, June 29, 1967) (Kahn, Arbitrator).

23 Id.

24 The district court approved the arbitrator's abstention from statutory issues. See 291 F. Supp, at 789. It should be recalled that the company's interpretation had been issued after the passage of Title VII. That interpretation had, moreover, been the basis of discipline and an arbitration award resting on the contract and plant practice. Reynolds Metals Co. v. Local 227, UAW (unpublished award, June 29, 1967) (Kahn, Arbitrator). Under those circumstances, the arbitrator's disregard of Title VII, even as a guide to interpretation of vague contractual language, seems sound.

$25291 \mathrm{~F}$. Supp. at 789.

26300 F. Supp. 709 (W.D. Mich. 1969).

27374 U.S. 398 (1963).

2829 C.F.R. \& 1605.I (1967).

20 The Sixth Circuit said that application of the regulation which was in force at 
We shall leave to other forums the merits of the Title VII question and focus on the Sixth Circuit's argument for reversing the procedural determination, which went like this: First, the Steelworkers' Trilogy ${ }^{30}$ would have barred the company from relitigating an arbitral award in favor of Dewey. ${ }^{31}$ Second, when grievances are based on an alleged civil rights violation, an arbitrator has a right to make a determination of such a grievance binding on both parties. Otherwise, arbitration would bind the employer but not the employee, and such one-sidedness would sound the death knell of labor arbitration. ${ }^{32}$

The court's approach, which has been uniformly criticized in the law reviews, ${ }^{33}$ does not withstand analysis. First, the Steelworkers' Trilogy accords finality to arbitral awards dealing with the law of the shop and not the law of the land. Indeed, the celebrated dictum in Enterprise Wheel, to which I have already referred, ${ }^{34}$ suggests that Mr. Kahn's award, had it been based solely on Title VII and not on the contract, would for that reason alone have been assailable as beyond his jurisdiction. Such an award, if based on an erroneous view of the statute, would also have been subject to judicial correction regardless of whether an employer or an employee benefited from that error. As the Fifth Circuit put it in Hutchings $v$. United States Industries, Inc., "Gongress ... has made the federal judiciary, not the EEOC or the private arbitrator, the final arbiter of an individual's Title VII grievance." The Sixth Circuit's fears of one-sidedness in the context of the Dewey case are thus wholly unfounded; they result from a failure to keep in mind the distinctive institutional competence of arbitrators, who are the monitors of the bargain, and of courts, who guard the law. With respect to the contractual determinations made by the arbitrator in Dewey, both parties could have secured only the most limited judicial review. But if the arbitrator had made any statutory determinations that did not coalesce with contractual determinations, both parties could have had

the time of Dewey's discharge would have been "more appropriate." 429 F.2d at 329 (1970).

30 United Steelworkers v. American Mfg. Co., 363 U.S. 564 (1960); United Steelworkers จ. Warrior \& Gulf Navigation Co., 363 U.S. 574 (1960); United Steelworkers v. Enterprise Wheel \& Car Corp., 363 U.S. 593 (1960).

31429 F.2d at $381-32$.

32 Id. at 332.

33 E.g., Edwards \& Kaplan, supra note 10, at 641-49 (1971); Gould, Labor Arbitration of Grievances Involving Racial Discrimination, 118 U. PA. L. REv. 40 (1969); Hebert \& Reischel, Title VII and the Multiple Approaches to Eliminating Employment Discrimination, 46 N.Y.U.L. REv. 450, 468, 471 (1971); Comment, Dewey v. Reynolds Metals Co.: Labor Arbitration and Title VII, 119 U. PA. L. REV. 684 (1971).

34 Text at note 13 supra.

35 428 F.2d 303, 313-14 (5th Cir. 1970) (emphasis in original). 
the right to comprehensive judicial review. Accordingly, the asserted one-sidedness did not exist. In any case, arbitrator Kahn did not, as we have seen, purport to deal with statutory questions. To foreclose Dewey's statutory rights in such a situation would be to deny him the right to be heard by either an arbitrator or a court and would appear to be plainly repugnant to due process notions.

It is true that in cases in which statutory and contractual issues overlap and the arbitrator resolves an issue common to both proceedings, unimpeded access to the courts on the basis of Title VII might, as we will see in a moment, result in the one-sidedness that concerned the court. But Dewey was not such a case because the resolution of the contractual issue, even if it were conceded to be correct, would not have affected the statutory claim. Furthermore, even in the overlap situation, the Sixth Gircuit's concern about the death of labor arbitration was somewhat exaggerated. This is not to deny the legitimate interest of employers, as well as of unions, in avoiding the burden of successive arbitral and judicial proceedings. But in an area already replete with overlapping remedies, arbitration aside, that interest is unlikely to override the parties' strong mutual interests in preserving a mechanism for resolving a broad range of disputes that do not impinge on Title VII.

Two Sixth Gircuit decisions subsequent to Dewey continue to reflect a strong commitment to the protection of arbitration and serve also to illuminate the weaknesses of that decision. First, in Tipler v. E.I. duPont deNemours of Co. ${ }^{36}$ that circuit held that a Title VII action was not barred by the NLRB's dismissal of a complaint based on the finding that an aggrieved Negro employee had been dismissed for cause rather than as a reprisal by a white foreman ousted from a union office after a racially oriented election campaign led by the discharged employee. The court distinguished Dewey in part on the ground that relitigation of the dispute would not undermine the arbitration system. ${ }^{37}$ The court also relied on the legislative history of Title $\mathrm{VII}^{38}$ and on the ground

36443 F.2d 125 (6th Cir. 1971).

37 Id. at 130 .

$38 I d$, at 129 . The court relied in part on Sen. Joseph Clark's well-known memorandum inserted in 110 CoNG. REc. 7207 (1964): "Nothing in Title VII or anywhere else in this bill affects the rights and obligations under the NLRA and the Railway Labor Act. The procedures set up in Title VII are the exclusive means of relief against those practices of discrimination which are forbidden as unlawful employment practices . . . . Of course, Title VII is not intended to and does not deny to any individual, rights and remedies which he may pursue under other Federal and State statutes. If a given action should violate both Title VII and the National Labor Relations Act, the National Labor Relations Board would not be deprived of jurisdiction. On the other hand, where the procedures of Title VII are involved, the remedies available are those set out in Section 
that the National Labor Relations Act is aimed at discrimination. that affects concerted activities while Title VII's proscription operates without regard to the effect of the disputed conduct on such activities. ${ }^{39}$ Although that point is incontestable, ${ }^{40}$ the complaint in Tipler rested fundamentally on the claim that the discharge had been a result of the racially oriented election campaign that had ousted the foreman. Consequently, the charge of racial discrimination cognizable under Title VII coalesced with the charge to the NLRB that dismissal had resulted from union activities. Indeed, the court seemed to acknowledge this coalescence when it declared that "[a]llegations of racial motivation were inherent in the [employee's] complaints to the NLRB" and when it did not question the contention that "he had twice previously maintained ... that his discharge was the product of union activities."41 That overlap and the NLRB's resolution of the question common to both proceedings strengthened the case for preclusion of Title VII remedies in Tipler. Furthermore, although the charging party is invariably allowed to intervene and participate through his counsel in NLRB proceedings, ${ }^{42}$ this privilege is considerably less certain in arbitration. ${ }^{43}$ Finally, the NLRB plainly does not suffer from certain institutional limitations on arbitration that I shall refer to in a moment. All in all, those considerations appear to make Tipler a much stronger case for preclusion than Dewey, even though no question of undergirding arbitration arises in the former case. In making that comparative statement, I do not mean to question the result in Tipler or the court's emphasis on the different focuses of the NLRA and Title VII, respectively.

In the second post-Dewey case, Spann v. Kaywood Division, Joanna Western Mills, ${ }^{44}$ the Sixth Circuit again confronted the problem of coordinating arbitration and Title VII. Although the court assimilated

707 (e) [subsequently renumbered 706(g)], injunctive relief against continued discrimination, plus appropriate affirmative action including ... backpay."

39443 F.2d at 129.

40 It should be observed, however, that Judge Wright's position in Packinghouse Workers v. NLRB, 416 F.2d 1126, 1135 (D.C. Cir. 1969), cert. denied, 396 U.S. 903 (1969), would, at least with respect to racial discrimination, eliminate this distinction between the two statutes since Judge Wright postulates that racial discrimination leads to docility among its victims, which in turn discourages concerted activity. This is not the place to consider the psychological or legal basis for that position.

41443 F.2d at 130 .

4229 C.F.R. \$ 102.29 (1971); T. Kammholz \& K. McGuiness, Practice and Procedure Before the National labor Relations Board 93 (1962).

43 See Atleson, Disciplinary Discharges, Arbitration and NLRB Deference, 20 Bufrsco L. REv. 355, 384-85 (1971); Shapiro, Some Thoughts on Intervention Before Courts, Agencies and Arbitrators, 81 HARv. L. REv. 721, 728-29, 769-72 (1968).

44446 F.2d 120 (6th Cir, 1971). 
Dewey and Spann, the two cases were significantly different. Spann,. a Negro, had written a white woman coworker a note asking her for a date. Despite a warning by the employer to desist, instigated by the union president, Spann wrote a similar note to another white coworker. Spann was immediately fired over the protest of the union vice-president, who objected not to the imposition of some penalty but only that discharge was too severe. Spann's discharge was ultimately the subject of an arbitration proceeding under a contract that provided: "Equal pay must be paid for equal work and equal privileges must be granted regardless of race, creed, or color." The arbitrator, although conceding that Spann's epistles had caused discontent in the plant, held that discharge had been an excessively severe penalty. He awarded reinstatement to Spann but denied him back pay and stated: "While the race element was an important factor in the instant series of events, it is pure conjecture to hold that the same results might not have occurred if the grievant were white." 45 That statement seemed to be a finding by the arbitrator that, but for racial considerations, there was at least a substantial doubt that Spann's conduct would have led to his discharge, and that, accordingly, racial considerations had been a factor in his discharge. Such a discharge would appear to constitute a violation of Title VII. ${ }^{46}$

Spann, although he accepted the reinstatement awarded by the arbitrator, was not content with his partial victory. He went to the Michigan Civil Rights Commission, which rejected his complaint on the ground that "the issue of racial discrimination was taken up and not proven" and "was decided after a full and fair hearing by an independent third party." $47 \mathrm{He}$ then went to the EEOG, which rewarded his persistence with a "reasonable cause" letter, whereupon he filed suit in a federal district court. That court dismissed on the basis of Dewey, ${ }^{48}$ and the Sixth Circuit affirmed. Although the court emphasized that Spann had accepted the benefit of the generally favorable award, the court's limiting summary of its holding did not reflect that emphasis: "We hold only that where all issues are presented to bona fide arbitration and no other refuge is sought until that arbitration is totally complete, Dewey precludes judicial cognizance of the complaint." 40 The court also intimated that Dewey might have been inapplicable had the

$45 \mathrm{Id}$. at 122.

46 Cf. NLRB v. Barberton Plastics Prods. Inc., 354 F.2d 66 (6th Cir. 1965); Glover v. Daniel, 818 F. Supp. 1070 (N.D. Ga. 1969).

47446 F.2d 120, 122 (6th Cir. 1971).

481 .

49 Id. at 128 . 
grievant simultaneously with his resort to the grievance procedure used "court or agency processes." 50

If we accept the court's statement that the arbitration in Spann had resolved all issues pertinent to the Title VII claim, an important difference arises between Spann and Dewey. In Spann, unlike Dewey, the pertinent contractual provision required the arbitrator to rule on the contention at the core of Spann's Title VII claim-that race had been a factor in his discharge. The Sixth Circuit found, moreover, that the arbitrator had not only ruled on that issue but also that his ruling was compatible with the statutory standards. The finding of compatibility is, I have suggested, highly questionable. If, however, we put that difficulty aside, we reach the question that, on the basis of the court's analysis, was presented by Spann-whether an arbitrator's factual findings negating racial discrimination and based on standards compatible with the provisions of Title VII should foreclose an independent judicial determination of a Title VII claim.

Although I am not in favor of such foreclosure, I want first to mention the weighty considerations that support it when questions perti-

$50 \mathrm{Id}$. at 122-23.

Newman v. Avco Corporation, BNA Daily Lab. Rep. No. 212, Nov. 3, 1971, at D1 (6th Cir. Oct. 27, 1971), handed down after this article was completed, casts doubt on the continued vitality of Dewey, although these two cases are distinguishable on their facts. In Newman, the Sixth Circuit reversed a summary judgment in favor of the defendants, an employer and a union, in an action based on Title VII filed by a Negro plaintiff whose grievance protesting his discharge as discriminatory had been denied in arbitration. The court relied on the following grounds for not applying Dewey: First, the summary judgment deprived the court of an evidentiary record. Second, because of the exhaustion doctrine (note 59 infra), the plaintiff's recourse to the grievance-arbitration process was not "voluntary." Third, in the Title VII action (filed after the arbitration hearing but before the award), the plaintiff had charged that a union-employer conspiracy to deprive Negro employees of training had led to the plaintiff's inability to perform jobs other than the one from which he had been discharged. Although a lawyer personally retained by the plaintiff had urged the racial discrimination contention before the arbitrator, the union's refusal to make that contention had been relied on by the arbitrator in rejecting it. Those circumstances raised a fundamental question as to the fairness of the arbitration proceeding. Fourth, the contract did not expressly prohibit racial discrimination and confined the arbitrator to issues of contractual interpretation or application. Consequently, there was "grave doubt" that the arbitrator had the right "to finally decide" the discrimination claims.

Although Dewey did not involve allegations of "conspiracy" and "bad faith," the second and fourth points referred to above could have also been made in Dewey. Furthermore, the court in Newman emphasized that the plenary jurisdiction of the federal courts under Title VII could not be curtailed by private agreements and that Dewey had been based on policies reflected in res judicata and collateral estoppel. The court's emphasis on the involuntary nature of an individual grievant's participation in arbitration, coupled with his lack of control of the proceeding and the institutional deficiencies of arbitration in this context, raises serious questions as to the applicability of those concepts as a basis for arbitral foreclosure. 
nent to a Title VII claim have been resolved by an award made in an arbitral proceeding that was procedurally fair ${ }^{51}$ and governed by substantive standards compatible with those embodied in Title VII. Such foreclosure would presumably avoid social waste, harassment of an adversary, and manipulation of tribunals. As the doctrines of res judicata and estoppel by judgment make clear, the avoidance of those results has for a long time been a pervasive objective of our legal system, and the current overloading of all organs of adjudication make that objective especially appealing today. Furthermore, in part to achieve that objective, the NLRB, notwithstanding the plenary authority it is granted by statute, has adopted a policy of deferring to arbitration, subject to safeguards built into the Spielberg doctrine. ${ }^{52}$ Finally, other circuit courts have indicated that they would consider a similar approach in the Title VII context,, 53 and some law review commentators have endorsed such deferral..$^{54}$

My rejection of arbitral foreclosure of independent judicial determination rests primarily on what I consider to be the institutional limitations of arbitration as a remedy for individuals complaining about the kinds of discrimination proscribed by Title VII-limitations that involve a special risk that the interests of individuals will be submerged by collective interests. This point about the risk to individual interests is sensitive, difficult to document, and easy to exaggerate. Nevertheless,

51 For a comprehensive list of such safeguards, see Edwards \& Kaplan, supra note I0, at 651-52 (1971). Some of the safeguards proposed by Messrs. Edwards and Kaplan are discussed in text and note at note 53 infra.

62 See Spielberg Mfg. Co., 112 N.L.R.B. 1080, 1082 (1955), in which the Board declared that it would defer to arbitration awards where "the proceedings appear to have been fair and regular, all parties had agreed to be bound, and the decision of the arbitration panel is not clearly repugnant to the purposes and policies of the Act." For a useful criticism of the Board's doctrine, see Atleson, supra note 43. For a recent review of the application of the deference doctrine in various contexts and an instance of the Board's abstention pending arbitration, see Collyer Insulated Wire, A Gulf \& W. Syss. Co., 192 N.R.L.B. No. 150 (Aug. 23, 1971).

53 See, e.g., Spann v. Kaywood Div., Joanna W. Mills, Inc., 446 F.2d 120, 123 n.3 (6th Cir. 1971) (referring to the safeguards proposed in Edwards \& Kaplan, supra note 10, at 651-52, urging that the arbitrator had conformed to those criteria); Hutchings v. United States Indus., Inc., 428 F.2d 303, 314 n.10 (5th Cir. 1970). There is, however, reason to doubt that those criteria were satisfied in Spann. See text and note at note 47 supra; cf. Bowe v. Colgate-Palmolive Co., 416 F.2d 711, 714 (7th Cir. 1969) (declaring in a different context that the analogy to labor disputes involving the concurrent jurisdiction of the NLRB and arbitration was "conclusive").

54 Among those favoring an analogue of Spielberg are Coleman, Title VII of the Civil Rights Act: Four Years of Procedural Elucidation, 8 DuQuesNE L. REV. 1, 24 (1969-70); Edwards \& Kaplan, supra note 10, at 651-52; Developments, supra note 5, at 1227. Contra, Hebert \& Reischell, supra note 33, at 469-71; Peck, supra note 1, at 468; Comment, supra note 38 , at $691-94$. 
arbitration is shaped and administered by the union and the employer. They select and pay the arbitrator, make the record before him, and sometimes seek clandestinely to supplement it. The arbitrator's future employment depends on his acceptability to them or to groups sharing their interests, as distinguished from the individual aggrieved by alleged discrimination. One need not accept Judge Hays's denigration of the arbitration process ${ }^{55}$ to recognize that there is some basis for the fear that economic self-interest and the desire to be loved, which are linked with future acceptability, may distort adjudication even when there is complete harmony between the individual's interests and those of his representatives. The danger of such distortion is obviously increased when the interests of the individual and the union conflict. Cases cognizable under Title VII involve special risks of such conflict, for racial and other forms of proscribed discrimination often persist as a result of joint action or inertia by unions and management. In such cases, an arbitrator may, as Professor Blumrosen has put it, be asked to bite both hands that are feeding him. ${ }^{56}$

Even if one believes that the overwhelming majority of arbitrators would do their duty in such cases, there is no basis for imputing such a belief to Congress. On the contrary, the legislative history of Title VII points in the opposite direction. That history, although far from conclusive, suggests that overlap between Title VII remedies and those provided by the NLRA or the Railway Labor Act was not to affect the applicability of Title VII. ${ }^{57}$ Arbitral machinery subject to the Taft-Hartley Act performs substantially the same function as the grievance processes provided for under the RLA and is subject to a similar risk that the interests of individuals or minority groups in nondiscriminatory employment will be submerged. Accordingly, no basis exists for giving arbitral remedies a preclusive effect that was apparently to be denied to remedies provided by the RLA as well as the NLRB. ${ }^{58}$ If,

55 P. Hays, Labor Arbitration: A Dissenting View 112 passim (1966).

56 Blumrosen, Labor Arbitration, EEOC Conciliation and Discrimination in Employment, 24 ARB. J. 88, 94 (1969); see Gould, supra note 33, at 44, 46-47.

The Spann case raised some question about the union's commitment to the grievant's cause, for the union president had been responsible for drawing management's attention to the first letter and, apparently, for management's warning to the grievant.

57 See Hebert \& Reischel, supra note 33, at 460 \& n.54 (quoting from Senator Clark's memorandum, set forth in note 38 supra).

58 Differences in procedures under arbitration and Title VII actions constitute an additional reason against arbitral foreclosure. See Bowe v. Colgate-Palmolive Co., 416 F.2d 711, 715 (7th Cir. 1969). For example, there are serious questions regarding the availability and desirability of formal arbitral discovery. See generally R. SMITH, L. MERRIFLeLd, \& D. Rothschild, Collective Bargaining and Labor Arbitration 217-18 (1970) and authorities cited therein; Jones, The Accretion of Federal Power in Labor Arbitration- 
however, a court found a violation of Title VII, notwithstanding prior arbitral determinations that in substance denied such a violation, it should consider the arbitral determination in fashioning a remedy. For instance, such an award, if free from procedural unfairness, might well be a reason for denying back pay for the period between the arbitration award and the contrary judicial decision-at least where the aggrieved employee had not objected to resort to the arbitration mechanism.

My proposed rejection of a Spielberg analogue is, I recognize, vulnerable to several important criticisms. First, it would permit wholesale relitigation of all arbitral awards because of the possibility that arbitration, like all other forms of earthly adjudication, may occasionally be imperfect. Second, some safeguard against disloyal or incompetent union representation is already present in the union's duty of fair representation of all members of the bargaining unit. Third, deference to arbitration could be conditioned not only on safeguards such as those embodied in the Spielberg doctrine-procedural fairness and substantive standards compatible with Title VII-but also on additional safeguards, including an option to the grievant to be represented by his own counsel in arbitration and an explicit waiver by him of the right to invoke statutory remedies.

Even though such safeguards would provide a measure of protection for individual rights, they are not, in my view, sufficient to warrant the adoption of a Spielberg analogue. Breach of the duty of fair representation during the grievance-arbitration process is extremely difficult to prove, and litigation of alleged breaches is likely to be at least as timeconsuming as litigation under Title VII. For several reasons, the grievant's option to be represented by his own lawyer is of doubtful effectiveness in the arbitration context. First, a grievant who exercised that option would in effect be expressing his distrust of union representatives whose good will might be important in assembling witnesses and in other aspects of case preparation and for the grievant's continuing relationships within the plant. Second, the replacement of the union representative might suggest to the arbitrator that the union was no more enthusiastic about the merits of the grievance than the employer. Such signals place intolerable strains on the arbitral machinery and are,

The Example of Arbitral Discovery, 116 U. PA. L. REv. 830 (1968). Furthermore, arbitral discovery is unlikely to be as effective as the investigative action taken by the EEOC, the results of which are made available to the aggrieved employee, at least after he has instituted suit. See H. Kessler \& Co. v. EEOC, 3 F.E.P. Cas. 956, 964 (N.D. Ga. Sept. 27, 1971). In addition, there are manifest differences between the procedural frameworks for arbitration and judicial actions. See generally Comment, 45 N.Y.U.L. REv. 1316, 1322-23 (1970). 
I believe, incompatible with fair adjudication. A grievant's election of individual representation without knowledge of the foregoing difficulties would scarcely be an informed one. It is, moreover, not easy to convey an appreciation of those difficulties, and a careful effort to do so might undermine confidence in a particular arbitrator or in the arbitration process in general. Third, even if the preceding difficulties are put aside, arbitration would still be a suspect forum for an individual employee, notwithstanding his selection of his own advocate, as long as the selection of the arbitrator remained in the hands of the union and the employer.

Let me turn now to an issue that may appear at first glance to be a digression from our topic but which may fundamentally affect the functioning of the grievance-arbitration process when it overlaps with Title VII. I am referring to the effect that should be given to a settlement of Title VII claims worked out during the grievance procedure or, indeed, during an arbitration proceeding. Let us assume that the employee in his individual capacity and the union in its representative capacity accept such a settlement and that it is conditioned on the employee's waiver of his overlapping right of action under Title VII, which is clearly explained to him. Should such a settlement be given preclusive effect even though such effect is denied to an arbitral award? The difference between these two situations is, of course, that the settlement has been approved by an individual grievant and is not imposed on him by an arbitrator selected by others. To be sure, the settlement terms may reflect the skill and energy with which the union prepared and pushed the case. Nevertheless, an employee who had doubts about the union's commitment could have rejected the settlement. In the absence of evidence of neglect by the union or overreaching by the employer or the union, preclusive effect should, I believe, be given to such a settlement. This result would, of course, be consistent with the general policy of voluntary adjustment reflected in the statute.

\section{III}

The considerations mentioned earlier in discussing the effect to be given an arbitration award obviously bear on the third of our questions: Should the exhaustion of contractual procedures be a prerequisite for invoking statutory remedies? The case for such a requirement rests on the following considerations: First, when questions arising under a collective agreement are involved, the Supreme Court has in general required such exhaustion before permitting judicial enforcement of 
the agreement. ${ }^{50}$ Second, under the Spielberg doctrine, the NLRB has not only deferred to arbitration awards but also has indicated that the availability of arbitration might under some circumstances cause it to abstain from exercising its jurisdiction. ${ }^{60}$ Third, initial recourse to arbitration would be consistent with the policy, reflected in Title VII, of promoting conciliation and voluntary adjustments ${ }^{01}$ and might also reduce the formidable backlog of the EEOC ${ }^{62}$ and the courts. Fourth, when contractual questions are enmeshed with Title VII claims, courts, even though not bound by arbitral determinations of such claims, would have the benefit of the special insight credited to arbitrators with respect to contractual questions.

Despite these considerations, courts have rejected any exhaustion requirement in this context. ${ }^{63}$ That approach is, I believe, fully justified. The statute contains elaborate provisions for the exhaustion of state remedies ${ }^{64}$ but is silent with respect to contractual exhaustion, thereby implying that it was not to be required. Such a requirement would, moreover, do violence to other parts of the statutory machinery. Thus, if exhaustion of arbitral remedies were coupled with the Dewey doctrine of foreclosure, the statutory machinery would be wholly inapplicable to a significant segment of employment-that covered by grievance-arbitration procedures. Such a wholesale supersession of statutory remedies would be unwarranted. The employment areas covered by grievance-arbitration procedures have not been especially immune from the discrimination proscribed by the statute. Furthermore, those procedures are, as I have already suggested, subject to special deficiencies as weapons against such discrimination.

Exhaustion could, of course, be required without giving binding effect to arbitral awards. But such a requirement would involve delays in addition to the time periods precisely specified in Title VII for deferral to state agencies and for EEOG action. ${ }^{65}$ Furthermore, the

69 See Vaca v. Sipes, 386 U.S. 171, $184-87$ (1967); Republic Steel Corp. v. Maddox, 379 U.S. 650 (1965). But cf. Walker v. S. Ry., 385 U.S. 196 (1966).

80 See Dubo Mfg. Corp., 142 N.L.R.B. 431, 432 (1963), enforced, 353 F.2d 157 (6th Gir. 1965); Collyer Insulated Wire, A Gulf \& W. Syss. Co., 192 N.L.R.B. No. 150 (Aug. 23, 1971).

61 See Civil Rights Act of 1964, § 707(a), 42 U.S.C. \$ 2000e-6(a) (1964).

62 See Developments, supra note 5, at 1201-02.

63 See, e.g., Bowe v. Colgate-Palmolive Co., 416 F.2d 711, 714-15 (7th Cir. 1969); King v. Georgia Power Co., 295 F. Supp. 943 (N.D. Ga. 1968); cf. Culpepper v. Reynolds Metals Co., 421 F.2d 888, 892-93 (5th Cir. 1970).

64 Civil Rights Act of 1964, $\S$ 706(b)-(c), 42 U.S.C. $\$ \S 2000-5(b)-(c)$ (1964).

65 Id. $\$ \S 706(\mathrm{~b})-(\mathrm{e}), 42$ U.S.C. $\$ \S 2000 \mathrm{e}-5(\mathrm{~b})$ to (e). 
legislative history indicates, as we have seen, that the existence of overlapping statutory remedies should not affect the applicability of Title VII remedies. That'history strongly implies that access to these remedies should not be barred by the existence of contractual remedies, and that implication is reinforced by the institutional deficiencies of these remedies as weapons against employment discrimination.

\section{IV}

Even though exhaustion is not required, an employee aggrieved by discrimination may, of course, turn first to the grievance process, the familiar forum for employee complaints. Such a step, especially if it leads to arbitration, may take longer than the ninety-day limitation period for filing a charge with the EEOC. Our fourth question, whether the limitation period should be tolled while contractual remedies were being pursued, was raised in Culpepper $v$. Reynolds Metals Co., ${ }^{66}$ in which the Fifth Circuit, reversing the decision below, ruled in favor of such tolling where the grievance did not go to arbitration. The court emphasized that statutes of limitation are directed at those who sleep on their rights and not those who invoke familiar and informal remedies established by the "rules of the shop."67 Furthermore, it suggested that limitation statutes must be subordinated to the interests of justice and the purposes of a "humane and remedial Act." 68 Finally, the tolling of the limitation period would, the court urged, encourage initial resort to the grievance-arbitration process in accord with the policy reflected in the Steelworkers' Trilogy. ${ }^{69}$ Accordingly, a grievant who invoked his contractual remedies should not, the court concluded, be "penalized" by the destruction of his statutory rights through the running of the limitations period. Given the fact that many victims of discrimination are not sophisticated with respect to the availability and suitability of alternative remedies, the court's result is a desirable one. Here, again, prior and unsuccessful recourse to the grievance process is a factor to be considered in connection with judicial awards of back pay for violations of Title VII. ${ }^{70}$ Incidentally, it remains to be seen whether the six-month limitation period embodied in section $10(\mathrm{~b})$ of the NLRA as amended would also be tolled by resort to the grievance process.

66421 F.2d 888 (5th Cir. 1970).

67 Id. at 892.

$68 \mathrm{Id}$.

$69 \mathrm{Id}$.

70 It is fairly arguable that back pay should be denied for the interval between a dismissal of a grievance and the judicial decision upholding the claim of a Title VII violation. 
Culpepper suggests another interesting question, the converse of the one involved in that case. Suppose an employee with a complaint cognizable under both the grievance-arbitration procedure and Title VII utilizes his statutory remedy and then seeks to invoke the grievance procedure after the running of the limitation period prescribed in the contract. Should the running of the contractual period be suspended for the period in which statutory remedies were invoked? That result plainly could not be supported as a means of encouraging resort to arbitration or on the ground that there were special difficulties in utilizing the statutory procedures where racial discrimination was involved. Such a suspension could, however, be defended on two other grounds invoked in Culpepper. First, the employee had not slept on his rights and thus had warned the employer of the need to preserve pertinent evidence. Second, limitation periods should be subordinated to the requirements of "justice," which might in this context mean preserving all available remedies and giving an employee whose statutory claim is denied an opportunity to pursue his contractual remedies. Arbitrators may, however, find these considerations an insufficient basis for enlarging contractually prescribed limitation periods.

Problems of limitations could be avoided by simultaneous pursuit of contractual and statutory remedies. But simultaneous actions would involve waste of scarce social resources and possible harassment of alleged offenders. ${ }^{71}$ In Bower $v$. Colgate-Palmolive Co., ${ }^{72}$ a federal district court sought to avoid such results by requiring plaintiffs who had invoked their statutory remedies to elect between their statutory and contractual remedies prior to any decision on the merits in any forum. The Seventh Circuit reversed, holding that arbitral and statutory jurisdiction was concurrent. ${ }^{73}$ It found conclusive the analogy to labor disputes that are subject to concurrent jurisdiction of arbitrators and the NLRB. It emphasized that there might be crucial differences between the processes and the remedies under arbitration and Title VII. It recognized that an arbitrator might restrict himself to the contract and ignore the statute but did not expressly discuss situations in which contractual issues would coincide with or overlap statutory issues. The court announced only one restriction with respect to

71 In view of these costs, the Sixth Circuit's intimation in the Spann case that a grievant might avoid arbitral foreclosure of his statutory remedy if he simultaneously invoked both remedies (text at note 50 supra) is questionable. The intimation may reflect an erroneous assumption that recourse to one of two concurrent remedies necessarily involves a waiver of the second remedy. See Comment, supra note 33 , at 685-89.

72272 F. Supp. 332 (S.D. Ind. 1967).

73 Bowe v. Colgate-Palmolive Co., 416 F.2d 711 (7th Cir. 1969). 
multiple proceedings-a manifestly sound bar against unjust enrichment through the pyramiding of remedial damage awards. ${ }^{74}$

Before concluding, I want to acknowledge that my inquiry suffers from a serious limitation in that $I$ have concentrated on situations in which claims cognizable under Title VII have been pressed in more than one forum. Preoccupation with such cases may have suggested that interaction between Title VII and arbitration has involved a substantial amount of social waste and litigious harassment of employers. That conclusion does not, however, appear to be warranted. On the contrary, what is striking, in view of the substantial overlap between arbitration and Title VII, ${ }^{75}$ is the relatively few reported cases in which arbitration awards have been challenged in Title VII proceedings. ${ }^{76}$

I do not have a firm explanation for that happy circumstance. But one plausible hypothesis is that arbitrators have, on the whole, done a good job of finding employment discrimination when it existed or, at least, of convincing grievants, their lawyers, and the EEOC that claimed discrimination did not exist or could not be proved. That hypothesis, if validated, would suggest that arbitrators have risen above the institutional limitations $I$ have emphasized and have by their integrity and craftsmanship achieved a pleasing kind of finality-finality without compulsion of law. Perhaps the prospect of an independent judicial check has contributed to that result by making all participants in arbitration more sensitive both to the special problems of grievances that overlap with Title VII and to the importance of the goal of that Title. In any event, whatever the ultimate fate of the Spielberg analogue and whatever role is accorded to law in arbitration, the grievance-arbitration process is likely to remain an important weapon against employment discrimination, and arbitrators are likely to continue to play an important role in advancing the national goal of equal employment opportunity.

74 Id. at 715.

75 A Bureau of National Affairs survey indicates that forty-six percent of a sample of collective bargaining agreements contained clauses barring discrimination on account of race, creed, or national origin. Bureau of National Affatrs, Labor ReLatTons Yearbook1969, at 34 (1970).

76 For a list of the pertinent cases, see Comment, supra note 58, at 1317 n.10. 